\title{
Optimization of various Parameters for the Performance Enhancement of PEM Fuel Cell
}

\author{
Velmurugan Pavanan ${ }^{1}$ and Lakshminarayanan Varadharajan ${ }^{2 *}$ \\ 'Mechanical Engineering Department, Malla Reddy College of Engineering, \\ Hyderabad - 500100, Telangana, India; velmurugan_mech@mrce.in \\ ${ }_{2}^{2}$ Mechanical Engineering Department, B. V. Raju Institute of Technology, Narsapur \\ Hyderabad - 502313, Telangana, India; lakshminarayanan.v@bvrit.ac.in
}

\begin{abstract}
Objectives: In this paper, the experimental analysis of various parameters on $25 \mathrm{~cm}^{2}$ interdigitated flow channel have been used for performance enhancement of Polymer Electrolyte Membrane (PEM) fuel cellby optimization technique. Methods/ Statistical Analysis: The design parameter like Landing to Channel width ratio-(L:C) and two operating parameters like back pressure and cell temperature have been considered. Here, Taguchi technique and analysis of variance methodology (ANOVA) have been used to obtain the optimum combination for the above three parameters. Three factors and three levels, such as design parameter as ( L:C- 1:1, 2:2 and 1:2) and operating parameters as cell temperature like 40, 50 and $60^{\circ} \mathrm{C}$ and back pressure $0,0.5$ and 1 bar have been taken for optimization studies. Findings: This study has revealed that the selected parameters 1 bar for back pressure, $60^{\circ} \mathrm{C}$ of cell temperature and landing to channel width ratio of $1: 2$ yield the maximum power density $0.265 \mathrm{~W} / \mathrm{cm}^{2}$ for interdigitated flow field. Also, multiple regression analysis studies have been carried out, and the regression co-efficient obtainable is $94.7 \%$ for inter-digitized flow fields with allowable maximum deviation limit is $5.3 \%$. The maximum deviation of $1.156 \%$ has been occurred between the experimental data and regression model analysis. Also, the F and P tests carried out in this study indicated that the back pressure is having major impact on performance of the PEM fuel cell. The back pressure is contributing $81.8 \%$ for overall cell performance followed by L:C and cell temperatures has $13.50 \%$ and $0.80 \%$ respectively.
\end{abstract}

Keywords: Design Parameter, Optimization, PEM Fuel Cell, Operating Parameter, Taguchi Technique, ANOVA

\section{Introduction}

Hydrogen fuel cells are being commercialized because of it produces high energy density in low operating temperature and energy conversion device that actually have less environmental impact than internal combustion engines. Hence this feature of PEM fuel cell leads to compete in automobile industry, portable and stationary power generation. It will be the clean technology of choice in future hydrogen economy when our fossil fuel runs out $^{1}$. The various parameters like pressure, cell temperature, humidification of reactant and flow rate of reactant gases which influencing the PEM fuel cell performance has been investigated ${ }^{2}$. The result concluded that the fuel cell performancewas increased with increasing operating pressure and cell temperature. The performance of PEM fuel cell with various parameters analyzed $\frac{3.4}{\text {. The }}$ result revealed that the cell performance was increased by increasing temperature and pressure due to the reactant gas diffusivity. Especially the pressure had shown the main parameter to influence the cell performance. The various parameters of fuel cell optimized with Taguchi method and neural network combined for the performance enhancement ${ }^{5}$. The result showed that the operating pressure and temperature had the most important parameters to affect the performance PEM fuel cell.

*Author for correspondence 
The performance of PEM fuel cell stackwith various operating parameterswas analyzed by Taguchi method to know the optimum parameter condition. The result showed the operating pressure had the main parameter to affect the stack performance ${ }^{6}$. The PEM fuel cell performance with many design parameters like pin type channels, straight and serpentine channels, integrated and inter-digitized channels has been studied ${ }^{7}$. The result concluded that the serpentine and interdigitated showed better performance than other flow channel design. Thevarious flow channel model was examinedto enhance the performance of PEM fuel cell. The result concluded that the diffusion mechanism of serpentine flow channel is the reason for reactant gases transportation. But in inter-digitized flow field, both diffusion and forced convection transport mechanisms were used to transfer reactant gases which cause reduced water flooding in the cathode gas diffuser hence, offered more power density than the conventional flow channeldesign ${ }^{-}$. The effects of four flow-distributor geometries (interdigitated, co-flow and counter-flow channels and foam) on the cathode side of PEM fuel cell was studied and concluded that the interdigitated flow channels have capability of sustaining higher current densities, when compared to other flow-distributor geometries ${ }^{2}$. Optimization of operating parameters by Taguchi method carried out with numerical and experimental analysis to find the optimum value. The result was concluded that cathode humidification was the most significant factor to affectthe stack performance, trailed by operating temperature, anode humidification and flow orientation. Whereas fuel oxidant gases stoichiometry ratio has less significant parameter to affect the performance of PEM fuel cell $\stackrel{10}{ }$. The performance of interdigitated and serpentine flow channel of PEM fuel cell with many parameters has been optimized by Taguchi method numerically. The result revealed that the interdigitated flow channel showed better performance than serpentine flow channel ${ }^{11}$. Hence to know the influence of operating and design parameters on the PEM fuel cell performance enhancementand alsoto find out the best combination of the parameters for achieving maximum performance, numerous trials of experiments have to be conducted. Carrying out such large number of trials is highly difficult, time consuming and costlier. An optimization tool like Taguchi's method will be greatly useful to overcome the above challenge by effectively reducing the number of trials and cost as well. The Taguchi's Orthogonal Array (OA) analysis can be found elsewhere and this method also helps in evaluating the impacts of individual control factors $\frac{12,13}{2}$.

Many researchers have numerically and experimentally examined the various parameters for performance improvement of PEM fuel cell. Hence to increase the performance of PEM fuel cell by optimization process, Taguchi method can be integrated with other optimization approaches like grey relational analysis, artificial neural network, and genetic algorithm. In this work, the performance improvement of PEM fuel cell with $25 \mathrm{~cm}^{2}$ active area of interdigitated flow channel has been considered to analyze a design parameter and two operating parameters using Taguchi technique and analysis of variance methodology.

\section{Experimental}

Anode and cathode regions are supplied with pure hydrogen and oxygen, respectively. The performance of the PEM fuel cell is observed by Biologic-FCT 50S Fuel cell test station which is capable of measuring $5 \mathrm{~V}, 50 \mathrm{~A}$ and $250 \mathrm{~W}$ and this has been interfaced to a computer system using FC-Lab V.5.22 software package.

\subsection{Orthogonal Array Analysis}

In this study, $\mathrm{L}_{9}$ orthogonal array has been considered since, we have taken 3 independent variables with each variable having 3 sets of level values. The various parameters and their levels have been considered for the optimization studies are shown in Table 1.

Table 1. Experimental plan according to L9 (33)

\begin{tabular}{|l|l|l|l|}
\hline Ex.No & $\begin{array}{c}(\mathrm{A})-\mathrm{Back} \\
\text { Pressure }(\text { bar }\end{array}$ & $(\mathrm{B})-\mathrm{L}: \mathrm{C}$ & $\begin{array}{c}(\mathrm{C})-\text { Cell } \\
\text { Temperature }\left({ }^{\circ} \mathbf{C}\right)\end{array}$ \\
\hline 1 & 0 & $1: 1$ & 40 \\
\hline 2 & 0 & $2: 2$ & 50 \\
\hline 3 & 0 & $1: 2$ & 60 \\
\hline 4 & 0.5 & $1: 1$ & 50 \\
\hline 5 & 0.5 & $2: 2$ & 60 \\
\hline 6 & 0.5 & $1: 2$ & 40 \\
\hline 7 & 1 & $1: 1$ & 60 \\
\hline 8 & 1 & $2: 2$ & 40 \\
\hline 9 & 1 & $1: 2$ & 50 \\
\hline
\end{tabular}

The performance of the PEM fuel cell has been affected by controllable and uncontrollable noise sources. In 
order tominimize the uncontrollable noise effects; the experiment has been conducted four times to ensure the consistency of the result with same operating conditions. The 'Larger the Better' concept has been adopted for this analysis. Hence the power output of the fuel cell must be higherand their calculation has given below by using Equation 1.

$$
\frac{\mathrm{s}}{N}=-10 \log \left[\left(\frac{1}{\mathrm{r}}\right) \sum_{\mathrm{i}=1}^{\mathrm{r}}\left\{\frac{1}{\mathrm{y}_{\mathrm{i}}^{2}}\right\}\right]
$$

where,

$r$ - Number of trial for the levels of the noise factors

$Y_{i}$ - Average power density

In order to achieve the maximum power density, the experiments have been performed based on L9 Orthogonal Array (OA) by selecting optimum combination of all parameters. The signal to noise ratio is nothing but the ratio of controlled and uncontrolled factors and it can be calculated by using Equation 1 .

\section{Results and Discussion}

The influences of control parameters (L:C, back pressure and cell temperature) and their levels (1:1, 2:2, 1:2 and 0 , $0.5,1$ bar and $40,50,60^{\circ} \mathrm{C}$ ) as per $\mathrm{L}_{9}\left(3^{3}\right)$ orthogonal array selected for improving the power density of interdigitated flow channel of PEM fuel cell.

Figure 1 shows the comparison of optimized results for various cell temperatures and various back pressures for 1. L:C -1:1, 2. L:C - 2:2 and 3. L:C - 1:2 with experimental number 1, 4, 7 and 2, 5, 8 and 3, 6, 9 respectively.

The peak power density was obtained for the L:C-1:1 has 225,239 and $260 \mathrm{~mW} / \mathrm{cm}^{2}$ at $0 \mathrm{bar}, 40^{\circ} \mathrm{C}$ and $0.5 \mathrm{bar}$, $50^{\circ} \mathrm{C}$ and $1 \mathrm{bar}, 60^{\circ} \mathrm{C}$ respectively. The same study has been conducted for the optimum combination of LC-1:2, 1 bar and $60^{\circ} \mathrm{C}$. The maximum peak power density obtained as $265 \mathrm{~mW} / \mathrm{cm}^{2}$ hence the percentage deviation between maximum and optimum was 2 . Figure 2 shows the peak power density was obtained for the L:C-2:2has 237, 251 and $263 \mathrm{~mW} / \mathrm{cm}^{2}$ at $0 \mathrm{bar}, 50^{\circ} \mathrm{C}$ and $0.5 \mathrm{bar}, 60^{\circ} \mathrm{C}$ and $1 \mathrm{bar}, 40^{\circ} \mathrm{C}$ respectively. The same study has been conducted for the optimum combination of LC-1:2, 1 bar and $60^{\circ} \mathrm{C}$. The percentage deviation between maximum and optimum was 1 . Figure 1(c) shows the comparison of optimized combination results obtained for L:C-1:2 with experimental numbers 3, 6 and 9 for 0 bar pressure and $60^{\circ} \mathrm{C}$ temperature, 0.5 bar and $40^{\circ} \mathrm{C}$, and operating pressure $1 \mathrm{bar}$ and temperature $50^{\circ} \mathrm{C}$ respectively. The peak power density obtained as 241,252 and $265 \mathrm{~mW} / \mathrm{cm}^{2}$ and there is no deviation in the peak power performances between optimum combination and experimental number 9 .

The commercial software MINITAB 14 has been utilized for the Design Of Experiments (DOE). The experimental results and calculated values obtained based on the plan of experiments, have been analyzed with the software. The mean effects plots for signal to noise plots have been automatically generated during the analysis. The factors are classified into signal (control factors) and noise (uncontrolled factors). The maximum signal to noise ratio should show the level of factors at which the maximum power density is obtained.From the results observed from Figure 2, it could be seen that 1 bar of back pressure, landing to channel ratio-1:2 and operating temperature $60^{\circ} \mathrm{C}$ are the optimum factors to show the better performance of PEM fuel cell. Table 2 exhibits the experimental results with 4 trails for interdigitated flow channel. The influences of controlled process parameters such as back pressure, L:C and cell temperature have been analyzed. The delta value and rank according to the significance factor have been mentioned in the Table 3. Maximum delta value shows higher ranking. From Table 4 , it can be learnt that, among all the factors considered for optimization studies, the back pressure is the most influential and significant parameter followed by L:C and cell temperature. Also it is observed that, the back pressure is providing highest influence of $81.8 \%$ contribution trailed by $13.5 \%$ of landing to channel width ratio and cell temperature of $0.8 \%$ contributed to the total performance of PEM fuel cell. This is because of theinterdigitated flow channel is having dead ended profiledesign. It is used to increase the reaction between reactants and catalyst. Also which is enhancing the reaction kinetics along with the back pressure effect which forcing the reactants to the catalyst sites.

Linear regression analysis has been employed for the present PEM fuel cell studies. The regression equation developed for interdigitated flow channelto estimate the power density is;

Power Density $\left(\mathrm{mW} / \mathrm{cm}^{2}\right)=214+28.4$ Back Pressure (bar) + 5.56 L:C + 0.184 Cell Temperature (deg.C) 


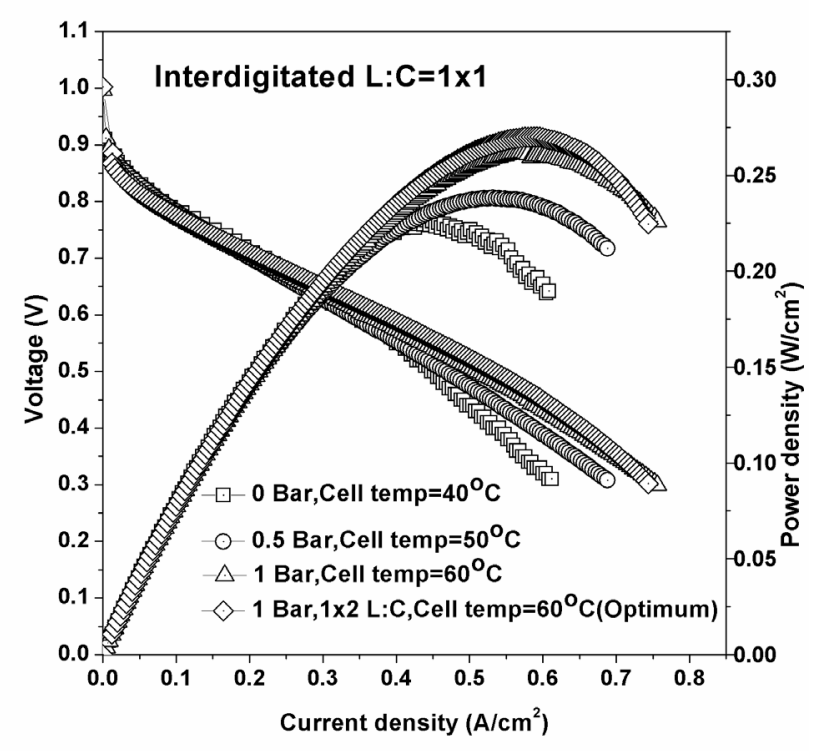

(a)

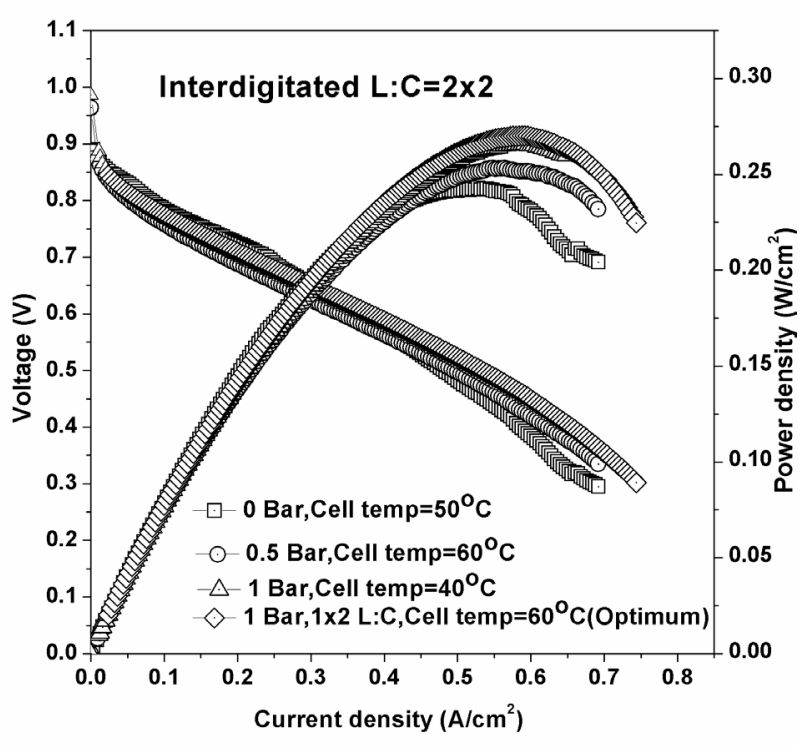

(b)

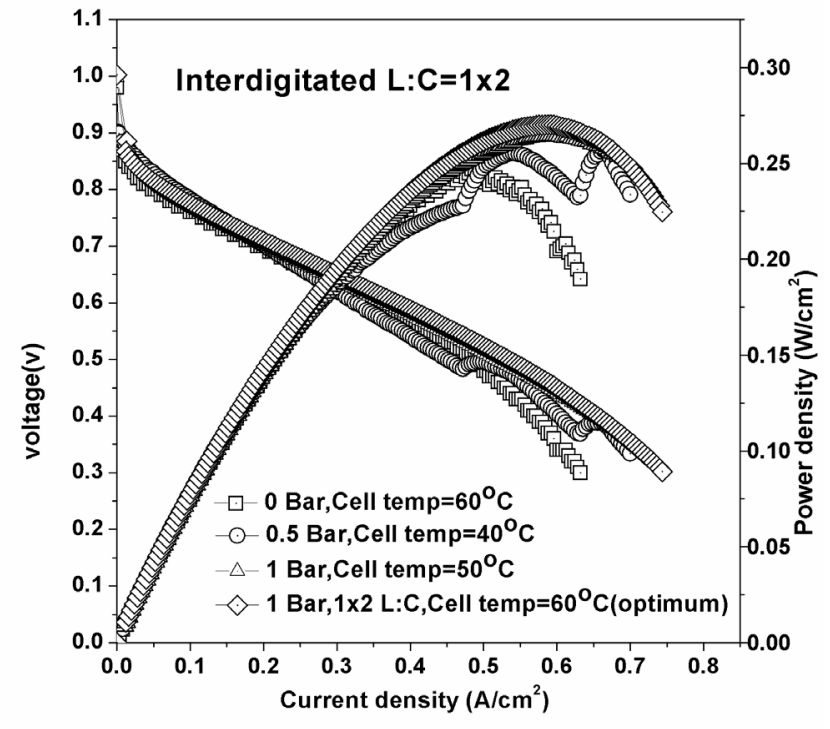

(c)

Figure 1. Polarization and performance curves of interdigitated flow fields for various L:C (a) 1:1 (b) 2:2 (c) 1 .

From the Equation 2, it has been observed that the co-efficient associated with all parameters have positive magnitude for inter-digitized flow field. Hence it clearly indicates that the back pressure is having major influence for obtaining maximum power density.The L:C and the temperaturesare having marginal impact of PEM fuel cell performance. Hence, in order to do the validation of the regression model, confirmation tests have been carried out by using a specific combination of the parameters and levels used for the analysis. The different parameter 


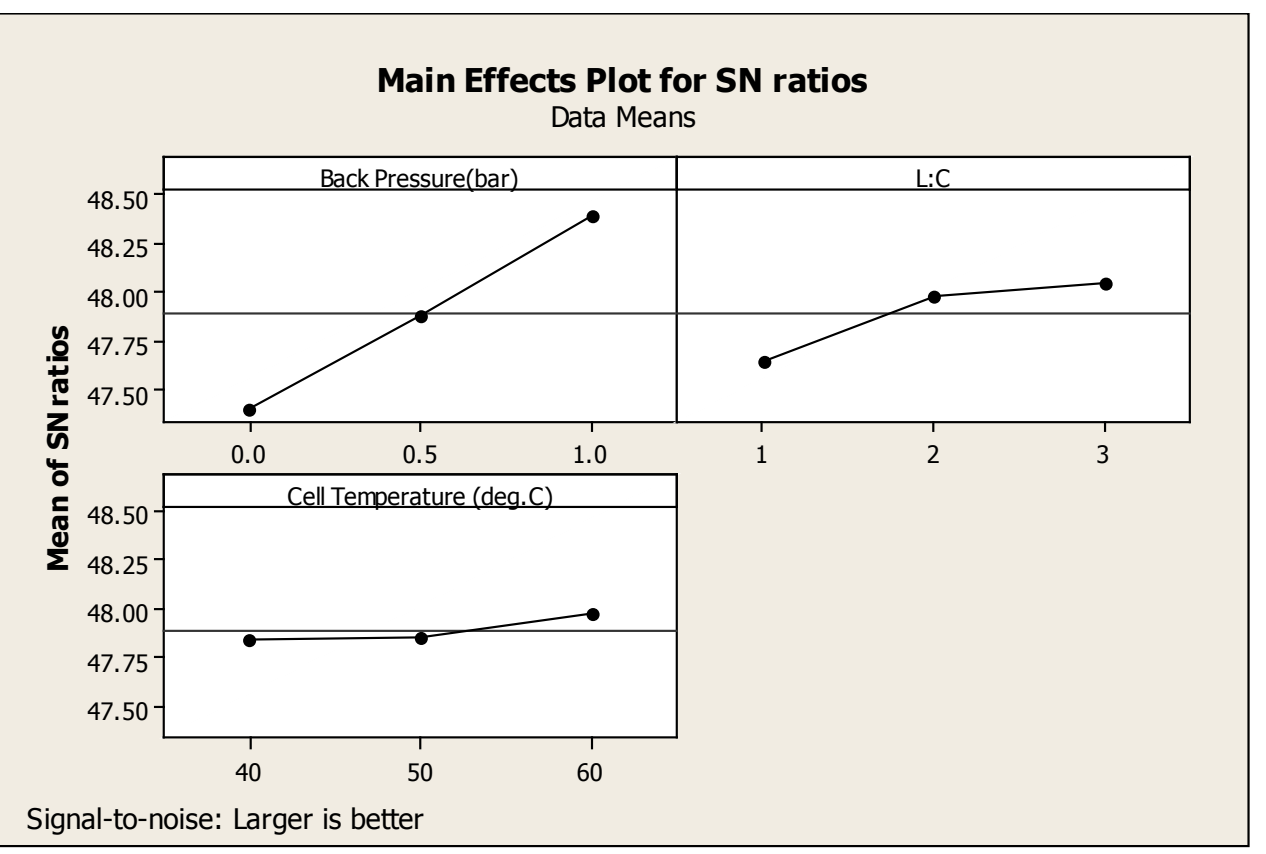

Figure 2. The $\mathrm{S} / \mathrm{N}$ ratios for interdigitated flow field.

Table 2. Experimental results for $\mathrm{L}_{9}\left(3^{3}\right)$ combination with various design and operating parameters

\begin{tabular}{|l|l|l|l|l|l|l|}
\hline Ex.No & $\begin{array}{l}\text { Power density-trail } \mathbf{1} \\
\left(\mathbf{Y}_{\mathbf{1}}-\mathbf{m W} / \mathbf{c m}^{2}\right)\end{array}$ & $\begin{array}{l}\text { Power density-trail 2 } \\
\left(\mathbf{Y}_{2}-\mathbf{m W} / \mathbf{c m}^{2}\right)\end{array}$ & $\begin{array}{l}\text { Power density- } \\
\text { trail 3 } \\
\left(\mathbf{Y}_{3}-\mathbf{m W} / \mathbf{c m}^{2}\right)\end{array}$ & $\begin{array}{l}\text { Power density- } \\
\text { trail } \mathbf{4} \\
\left(\mathbf{Y}_{4}-\mathbf{m W} / \mathbf{c m}^{2}\right)\end{array}$ & $\begin{array}{l}\text { Average Power } \\
\mathbf{d e n s i t y ~} \\
\left(\mathbf{Y}_{\mathbf{i}}-\mathbf{m W} / \mathbf{c m}^{2}\right)\end{array}$ & S/N ratio \\
\hline 1 & 224.793 & 224.997 & 225.606 & 225.403 & 225.20 & 47.051 \\
\hline 2 & 236.593 & 236.996 & 238.208 & 237.803 & 237.40 & 47.509 \\
\hline 3 & 240.339 & 240.495 & 240.960 & 240.805 & 240.65 & 47.627 \\
\hline 4 & 240.072 & 239.585 & 238.129 & 238.614 & 239.10 & 47.576 \\
\hline 5 & 252.372 & 251.786 & 250.028 & 250.614 & 251.20 & 48.004 \\
\hline 6 & 253.387 & 252.903 & 251.453 & 251.936 & 252.42 & 48.042 \\
\hline 7 & 259.876 & 260.0385 & 260.523 & 260.362 & 260.20 & 48.306 \\
\hline 8 & 261.202 & 262.301 & 265.598 & 264.499 & 263.40 & 48.412 \\
\hline 9 & 265.328 & 265.068 & 264.288 & 264.548 & 264.808 & 48.458 \\
\hline
\end{tabular}

Table 3. S/N ratio, Delta values for $25 \mathrm{~cm}^{2}$ interdigitated low channel

\begin{tabular}{|l|l|l|l|}
\hline Level & Back pressure & L:C & Operating temperature \\
\hline 1 & 47.40 & 47.64 & 47.84 \\
\hline 2 & 47.87 & 47.97 & 47.85 \\
\hline 3 & 48.39 & 48.04 & 47.98 \\
\hline Delta & 1.00 & 0.40 & 0.14 \\
\hline Ranking & 1 & 2 & 3 \\
\hline
\end{tabular}


Table 4. Result of the variance analysis for the maximum power density for interdigitated flow field

\begin{tabular}{|l|l|l|l|l|l|l|}
\hline Factors & $\begin{array}{l}\text { Degree of } \\
\text { freedom }\end{array}$ & Sum of squares & Variance & F-test & P-Test & $\begin{array}{l}\text { Percentage } \\
\text { Contribution }\end{array}$ \\
\hline A & 2 & 1210.795 & 605.397 & 84.723 & 0.016 & 81.8 \\
\hline B & 2 & 211.654 & 105.827 & 14.810 & 0.065 & 13.5 \\
\hline C & 2 & 14.291 & 13.174 & 1.843 & 0.092 & 0.8 \\
\hline Error & 2 & 14.291 & 7.145 & - & - & 3.9 \\
\hline Total & 8 & 1463.089 & - & - & - & 96.1 \\
\hline
\end{tabular}

levels chosen for the confirmation test plans are shown in Table 5.

Table 5. Confirmation test plans for interdigitated flow fields

\begin{tabular}{|l|l|l|l|}
\hline & \multicolumn{3}{|c|}{ Independent Variables } \\
\hline Experimental no. & A & B & C \\
\hline 1 & 1 & 1 & 1 \\
\hline 2 & 2 & 2 & 2 \\
\hline
\end{tabular}

Computation has been carried out after feeding the proper operating and design parameter values in Equation 2. A comparison of experimental values and computed value from regression model has given in the Table 6. It has clearly shown that the range of percentage deviation is being in between 0.325 to 0.757 for interdigitated flow channel.The maximum percentage deviation of experimental and obtained value from regression model is 1.156 .

Table 6. Validation of experimental result and regression model for maximum power density

\begin{tabular}{|l|l|l|l|}
\hline \multirow{2}{*}{ S.No } & \multicolumn{3}{|c|}{$\begin{array}{c}\text { Power density of } 25 \mathrm{~cm}^{2} \text { interdigitated flow } \\
\text { channel }\left(\mathbf{m W} / \mathrm{cm}^{2}\right)\end{array}$} \\
\cline { 2 - 4 } & Experimentation & $\begin{array}{c}\text { Regressionmodel } \\
\text { (Eqn. 2) }\end{array}$ & $\begin{array}{c}\text { Percentage } \\
\text { Deviation }\end{array}$ \\
\hline 1 & 225.2 & 226.92 & 0.757 \\
\hline 2 & 247.71 & 248.52 & 0.325 \\
\hline
\end{tabular}

\section{Conclusions}

The following conclusions havebeen arrived from present study.

- Taguchi technique and ANOVA methodology have been used to obtain the optimum combination and their contributions forperformance enhancement of the PEM fuel cell.The landing to channel width ratiol:2 and the operating parameters, back pressure of $1 \mathrm{bar}$, and cell temperature of $60^{\circ} \mathrm{C}$ have produced maximum power densities of $0.265 \mathrm{~W} /$ $\mathrm{cm}^{2}$ for inter-digitized flow field.

- Also, the F and P tests carried out in this study indicated that the back pressure is having major impact on performance of the PEM fuel cell. The back pressure is contributing $81.8 \%$ for overall cell performance followed by $\mathrm{L}: \mathrm{C}$ and cell temperatureshas $13.50 \%$ and $0.80 \%$ respectively.

- The multiple linear regression analysis indicatedthe $\mathrm{R}^{2}$ value has $94.7 \%$ for inter-digitized flow channel with allowable maximum deviation limit $5.3 \%$.

\section{References}

1. Owejan JP, Trabold TA, Jacobson DL, Arif M, Kandlikar SG. Effects of flow field and diffusion layer properties on water accumulation in a PEM Fuel Cell. Int J of Hyd Energy. 2007; 32(17):4489-502. Crossref.

2. Wang L, Liu H. Performance studies of PEM fuel cells with inter-digitized flow fields. J of Power Sources. 2004; 134(2):185-96. Crossref.

3. Amirinejad M, Rowshanzamir S, Eikani MH. Effects of operating parameters on performance of a proton exchange membrane fuel cell. J of Power Sources. 2006; 161(2):872-5. Crossref. 
4. Yu WL, Wu SJ, Shiah SW. Parametric analysis of the proton exchange membrane fuel cell performance using design of experiments. Int J of Hyd Energy. 2008; 33(9):2311-22. Crossref.

5. Wu HW, Gu HW. Analysis of operating parameters considering flow orientation for the performance of a proton exchange membrane fuel cell using the Taguchi method. J of Power Sources. 2010; 195(11):3621-30. Crossref.

6. Kaytakoglu S, Akyalcin L. Optimization of parametric of a PEMFC. Int J of Hyd Energy. 2007; 32(17):4418-23. Crossref.

7. Manso AP, Marzo FF, Barranco J, Garikano X, Garmendia Mujika M. Influence of geometric parameters of the flow fields on the performance of a PEM fuel cell - A review. Int J of Hyd Energy. 2012; 37(20):15256-87. Crossref.

8. Biyikoglu A. Review of proton exchange membrane fuel cell models. Int J of Hyd Energy. 2005; 30(11):1181-212. Crossref.
9. Birgersson E, Vynnycky M. A quantitative study of the effect of flow distributer geometer in the cathode of a PEM Fuel Cell. J of Power Sources. 2006; 153(1):76-88. Crossref.

10. Wu H W, Ku H W. Effects of modified flow field on optimal parameters estimation and cell performance of a PEM fuel cell with the Taguchi method. Int J Hyd Energy. 2012; 37(2):1613-27. Crossref.

11. Lakshminarayanan V, Karthikeyan P. Optimization of flow channel design and operating parameters on proton exchange membrane fuel cell using matlab. Periodica Polytechnic Chemical Engineering. 2009; 60(3):173-80. Crossref.

12. Logothetis N, Wynn HP. Quality through Design. Oxford: Clarendon Press; 1989.

13. Ross JP. Taguchi Techniques for Quality Engineering. New York: McGraw - Hill; 1988. 